\title{
Working
}

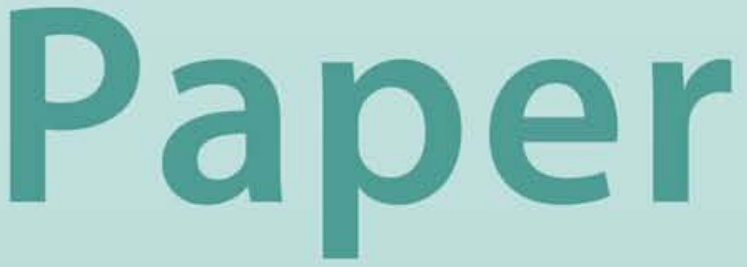




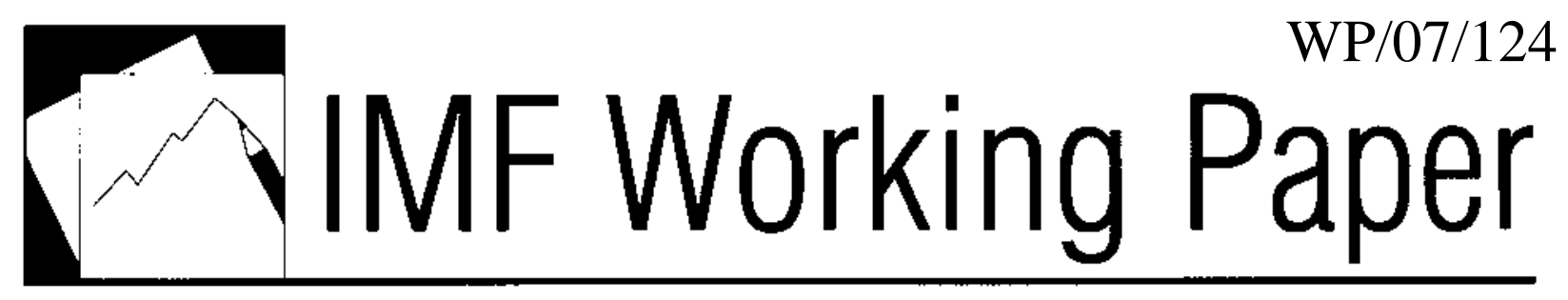

\section{Public Investment and Growth in the Eastern Caribbean}

Shaun K. Roache 


\title{
IMF Working Paper
}

Western Hemisphere Department

Public Investment and Growth in the Eastern Caribbean

Prepared by Shaun K. Roache ${ }^{1}$

Authorized for distribution by Paul Cashin

May 2007

\begin{abstract}
This Working Paper should not be reported as representing the views of the IMF.

The views expressed in this Working Paper are those of the author(s) and do not necessarily represent those of the IMF or IMF policy. Working Papers describe research in progress by the author(s) and are published to elicit comments and to further debate.

This paper quantifies the effect of public investment on growth in the ECCU. The results, emerging from panel vector autoregressions, indicate that the return on public investment, as defined by Perreira (2000), is very likely negative. This means that the total change in real output induced by one EC dollar of public investment, due to its short-run impact on demand, or the longer-run impact on supply, is below one EC dollar. Public investment shocks also appear to appreciate the real exchange rate, suggesting that the short-run demand impact is larger than the long-run supply response.
\end{abstract}

JEL Classification Numbers: E22, H54, 016, 054

Keywords: Public investment, growth, Caribbean

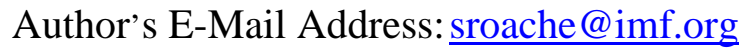

${ }^{1}$ The author is grateful to Paul Cashin, Mario Dehesa, colleagues in the Caribbean I Division, and seminar participants in the Western Hemisphere Department of the International Monetary Fund for helpful comments and suggestions. 
Contents

I. Introduction

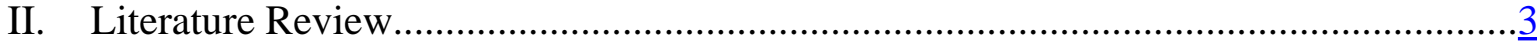

III. Data—Description and Trends.......................................................................

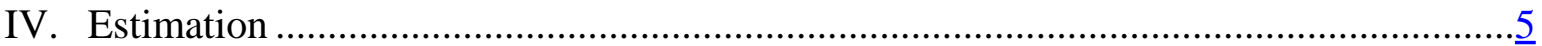

A. Panel Vector Autoregressions-Pros and Cons for the ECCU ...................... $\underline{5}$

B. Selection of Endogenous Variables ........................................................

C. Exogenous Variables_-OECD Growth, Aid, Natural Disasters and

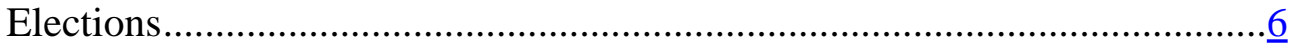

D. Model Specification and Estimation ..................................................

E. Impulse Responses....................................................................... $\overline{7}$

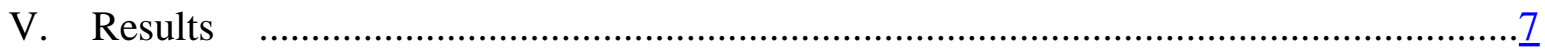

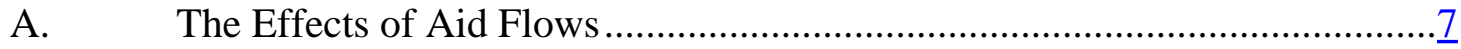

B. The Impact of Public Investment on Growth..............................................

C. Granger Causality Test—Public Investment on Output .............................. 10

D. The Impact of Growth on Public Investment............................................10

E. The Impact of Public Investment and Growth on the Bilateral RER ............11

F. $\quad$ Effects of Natural Disaster and Elections .................................................

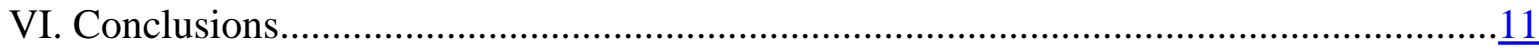

Tables

1. ECCU: Rate of Return on Public Investment ..................................................... $\underline{9}$

2. ECCU: Rate of Return Compared....................................................................... 10

Appendices

I. $\quad$ ECCU Public Investment Model: Summary Statistics .........................................12

II. Correlation Matrix of Model Variables ..............................................................12

III. VAR Coefficients on Natural Disaster and Election Dummy Variables.......................12

Figures

1. ECCU: Public Investment, Growth and Aid Inflows, 1975-2004...........................13

2. ECCU: Public Sector Investment, 1975-2004....................................................14

3. ECCU: Impulse Response for GDP and the Bilateral Real Exchange Rate to One Standard Deviation Public Investment and GDP Shocks .........................................15

4. ECCU: Accumulated Impulse Responses to a One Standard Deviation Shock to Public

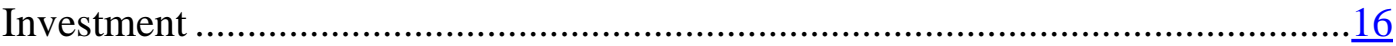

5. Accumulated Impulse Responses to a One Standard Deviation Shock to GDP ...........17

6. Accumulated Impulse Responses of the Bilateral RER to a One Standard Deviation Shock to GDP and Public Investment 


\section{INTRODUCTION}

Public investment has a high profile in the small islands of the Eastern Caribbean Currency Union (ECCU). ${ }^{2}$ In common with many small states, it accounts for a large share of GDP, averaging around 10 percent, compared to 3 percent for OECD countries (Figure 1). In part this not only reflects the limits of economies of scale in the provision of public goods, but also the regional perception that public investment is one of the main catalysts for economic growth and development.

This paper quantifies the effect of public investment on growth and the real exchange rate in the ECCU. Avoiding the imposition of too many priors on the data, an atheoretic approach is used. This has its drawbacks; the model will provide no information on why the results emerge as they do. However, this approach also has advantages. It allows us to make inferences based on past investment performance. It does so while avoiding imposing theoretical restrictions on an investment-growth process that, due in part to data limitations, is poorly understood.

The results, emerging from panel vector autoregressions indicate that the rate of return on public investment, as defined by Pereira (2000), is very likely negative. This means that the total change in real output induced by one EC (Eastern Caribbean) dollar of public investment, due to its short-run impact on demand, or the longer-run impact on supply, is below one EC dollar. This is not the only (or perhaps the best) way to measure the returns on public investment. However, it allows us to compare the results of the ECCU to those of other countries studied in the literature.

The plan of this paper is as follows: Section II provides a selective literature review. Section III describes the data. Section IV details the estimation procedures. Section V presents the results, and Section VI provides a brief conclusion.

\section{LITERATURE REVIEW}

Early work on the growth effects of public investment used the single-equation static production function approach and aggregate data. In its most basic form, this method assumes a production function in which output is a function of public capital $K^{G}$, private capital $K^{P}$, labor $N$, and technology $A$ :

$Y_{t}=F\left(A_{t}, K_{t}^{G}, K_{t}^{P}, N_{t}\right)$

Assuming a generalized Cobb-Douglas form, and allowing lower case variables to denote logs, and $\varepsilon$ to represent the elasticity of output with respect to factor $i$, this can be written as:

\footnotetext{
${ }^{2}$ In this paper, the ECCU refers to the six independent states of Antigua and Barbuda, Dominica, Grenada, St. Kitts and Nevis, St. Lucia, and St. Vincent and the Grenadines.
} 
$y_{t}=a_{t}+\varepsilon_{G} k_{t}^{G}+\varepsilon_{P} k_{t}^{P}+\varepsilon_{N} n_{t}$

Celebrated early results emerged from Aschauer (1989a, 1989b) with public capital seemingly having a powerful influence on output growth and productivity in the United States. Using a variation on equation (2), one specification used the productivity of private capital as the left-hand side variable, with capacity utilization represented by $\mathrm{cu}$ :

$y_{t}-k_{t}^{P}=a_{0}+a_{1} t+a_{2}\left(k_{t}^{G}-k_{t}^{P}\right)+a_{3}\left(n_{t}-k_{t}^{P}\right)+a_{4} c u_{t}+u_{t}$

Subsequent literature, surveyed extensively by Munnell (1992), presented more ambiguous results; in many cases, growth effects were absent.

Other notable examples include Khan and Kumar (1997), which used the neo-classical growth model, a cross-section of 95 developing countries and decade-long sample periods. Per capita growth rates were regressed on initial GDP per capita, population growth and technical change, and investment rates for the public and private sectors. Results suggest that while both types of investments have a positive and significant effect on growth, private investment tended to have a larger impact. Kavanagh (1997) focuses on Ireland, often cited as a role model for small states, over the 1958-90 period. Using a production function approach and error-correction methodology, results suggested that public capital had a positive, but insignificant effect on output per capita.

There are three criticisms of the structural modeling of aggregate production functions approach. First, there remain outstanding econometric problems, such as non-stationarity in the possible absence of cointegration and endemic endogeneity (see Jorgenson, 1991). Second, it ignores the dynamic relationship between public investment and growth. Third, research based on aggregate data does not allow for the varying effects of different types of public capital stock; public investment in infrastructure and social services may impact growth in very different ways, both in terms of scale and timing.

More recent research attempts to address these issues, with much use made of vector autoregressions (VARs), a field comprehensively surveyed by Kamps (2004). Notable contributions include Pereira (2000), which focusing on the United States, uses data on aggregate and five specific types of public investment, output, private investment, and private employment. The estimated long-run effect on output of a one percent, one-time random shock to aggregate public investment was 0.04 , with variaton according to the type of capital. Pereira and Fatima-Pinho (2006) used a similar VAR framework for the twelve euro-area countries. The same long-run effects on output were estimated to average 0.06 and ranged from -.20 in the Netherlands to 0.20 in Italy.

Kamps (2004) assesses public investment in 22 OECD countries. Using vector errorcorrection models and recursive identification prcedures, impulse responses showed that the effect of public capital on output is positive in the long-term, but with very large standard errors. The average long-run elasticity of output to a public investment shock is 0.12 , although this varies widely across countries. 


\section{DATA —DESCRIPTION AND TRENDS}

Estimations use annual data from 1975 to 2005. Public investment refers to capital expenditure undertaken by central government, public enterprises, and statutory corporations. The sources of the data are IMF staff reports and World Bank Country Economic Memorandums; this latter source proved particularly important for the pre-1995 period in which the Bank played an active role in developing public sector investment plans (PSIPs).

In almost all cases, these are taken from the presentation of the fiscal accounts, where it was not possible to identify the type of investment spending. Even when the World Bank helped develop the PSIP, the sectoral breakdown of investment data is on an approved and proposed basis only; in many cases, execution of the PSIP may be quite different from that proposed in the PSIP or the budget. Public investment was deflated using the average OECD deflator of capital expenditure for the federal government (excluding defence), and state and local governments. Summary statistics are presented in Table 1.

Figure 2 shows the ratio of public investment to GDP for the six ECCU countries (in current EC dollars). There are at least two interesting points. First, this ratio is relatively high.

Second, this ratio is volatile, with the average for the ECCU showing a standard deviation of 3 percent (compared to 0.3 percent for the OECD average).

Both the log of real GDP and the bilateral RER are non-stationary. The evidence that public investment is also I(1) is weaker, but this appears to be due to the effect of one country in the panel. Tests for cointegration, based on Pedroni (1999) were mixed, but in the most general specifications of the test there was little evidence of panel cointegration (results of all unit root tests are available upon request).

\section{ESTIMATION}

\section{A. Panel Vector Autoregressions-Pros and Cons for the ECCU}

The model used in this paper is a panel vector autoregression (PVAR). A reduced-form VAR entails certain limitations on the conclusions one may draw from the results. It is an atheoretic method that allows one to draw some inferences regarding the data-generating process, but it provides little guidance on the underlying economic relationships.

The advantages outweigh the disadvantages when assessing public investment in the ECCU, for four main reasons. First, many structural models rely on the existence of a fairly rich data set, including estimates of the public capital stock. While it is possible to derive estimates for the ECCU (e.g. Roache, 2006), the high incidence of natural disasters introduce huge uncertainty related to the rate of depreciation (or destruction) in particular years. Second, popular structural approaches tend to model other factor inputs, such as labor; the data for which simply does not exist in most of the ECCU countries. Third, a PVAR explicitly models dynamics, useful when considering the short- to medium-run impact of public investment, particularly in small economies in which the government plays a large role. Finally, and more generally, a PVAR approach avoids the thorny issue of endogeneity. 
Using a panel VAR improves the degrees of freedom of the results, but obviously imposes the restriction that the dynamics (but not necessarily the fixed-effects) are homogenous across the ECCU countries. Almost all previous studies have tended to use single-equation VARs. In this case, the panel approach was used on the assumption that the role of the public sector in the ECCU economies is relatively similar.

\section{B. Selection of Endogenous Variables}

Three endogenous variables were used in the PVAR — real GDP, real public investment, and the bilateral real exchange rate (RER) with the United States. This small list of domestic variables was dictated by reliable data availability.

The selection of the RER was motivated by the possible relationships between public investment and competitiveness, of which there are many. In the short term, a large rise in public investment could cause the internal real exchange rate to appreciate; since most physical capital is imported, the main price effect would be through greater demand for wages and a higher price for nontradable goods. In the long run, a higher public capital stock could encourage more private investment, boosting the domestic supply of tradables and nontradables and allowing the internal RER to depreciate. Conversely, Balassa-Samuelson effects might dominate, with higher tradable sector productivity leading to an appreciated RER.

\section{Exogenous Variables-OECD Growth, Aid, Natural Disasters and Elections}

The OECD growth rate was used as a control variable, contemporaneously and with a number of lags equal to those of the PVAR. Aid flows were also included as an exogenous variable to assess the effect of changes in external donor assistance. This is measured as explicit aid, rather than the implied benefits obtained from preferential trade agreements, an area explored in Mlachila and Cashin (2007). These data were deflated by the investment deflator, since it was assumed that most aid flows are used for investment projects rather than current spending. The model was run with and without the aid variable.

The inclusion of aid in the model may be controversial and likely raises as many questions as it answers. For example, is aid endogenous to any of the domestic variables, including the incidence of natural disasters? Correlations suggest that aid has only a weak contemporaneous relationship with the other variables. Also, a raft of panel regressions in which aid flows are on the left-hand side and domestic variables, including natural disaster dummy variables, are on the right-hand side suggested no relationship between domestic variables, including natural disasters.

Exogenous domestic variables include dummy variables for both natural disasters and elections. Natural disasters that affected either at least 25 percent of the population or caused more than 25 percent of GDP in damage were identified from the EMDAT database. Dummies were included for the year the disaster hit, and the following two years to control for the effect of disaster-related reconstruction, whose growth effects may be very different from regular public investment. There has been research suggesting that public spending in the ECCU may be affected by the election cycle (Duttagupta and Tolosa, 2006). To control 
for this, dummies for the year before and the year of national elections in each country were also included.

\section{Model Specification and Estimation}

To allow for heterogeneity, a fixed-effects model is estimated. As is well known, it is inappropriate to treat individual effects as constants to be estimated for a dynamic model (Nickell, 1981). Although the bias goes to zero as the time dimension gets very large, Judson and Owen (1996) show this bias may remain significant even with a time dimension of 30, close to that used in this paper. Following Holtz-Eakin, Newey, and Rosen (1988), the model is estimated in the first difference of growth rates, to sweep away the fixed effects. Denoting the (3x1) vector of endogenous variables (growth rates) as $\mathbf{x}$, the OECD growth rate as $\mathbf{w}$, and the vector of dummies as $\mathbf{f}$, this model may be written as:

$$
\Delta \mathbf{x}_{t}=\mathbf{a}_{0}+\sum_{l=1}^{m} \mathbf{a}_{l} \Delta \mathbf{x}_{t-l}+\sum_{l=1}^{m} \boldsymbol{\gamma}_{l} \Delta \mathbf{w}_{t-l}+\boldsymbol{\Theta} \mathbf{f}_{t}+\mathbf{v}_{t}
$$

The vector of instrumental variables $\mathbf{z}$ that is available to identify the model is:

$\mathbf{z}_{t}=\left[1, \mathbf{x}_{t-1}, \ldots, \mathbf{x}_{1}, \mathbf{w}_{t}, \ldots, \mathbf{w}_{1}, \mathbf{f}_{t}\right]$

The model was estimated using the Generalized Method of Moments (GMM) and a weighting matrix that controlled for heteroscedasticity of an unknown form. The set of instruments was chosen to ensure that the test of overidentifying restrictions was satisfied. The lag length of two was chosen on the basis of log-likelihood tests and, at the margin, information criteria.

\section{E. Impulse Responses}

The ordering used to obtain orthogonalized impulse responses was that public investment leads GDP, which leads the RER. This ordering is typical of the literature and was justified by Pereira (2000) on the basis that: (i) shocks to economic growth take time to feed through the policy function influencing public investment; (ii) public investment has an immediate impact on growth. These assumptions are all fairly uncontroversial. Impulse response standard errors were derived using Monte Carlo simulations, as outlined in Hamilton (p.337, 1994).

\section{Results}

\section{A. The Effects of Aid flows}

Aid, as noted above, is included in the study as a control variable; it is not the intention here to assess the effect of aid on growth. As might be anticipated from simple correlations, the inclusion of aid flows had little effect, only marginally reducing the public investment multiplier on growth. 


\section{B. The Impact of Public Investment on Growth}

Impulse responses suggest that public investment has a positive but short-run impact on growth (see Figures 3 and 4). Given the assumption of no cointegration, the model by definition implies that public investment cannot permanently affect the growth rate, but can permanently affect the level of GDP. The effect of a one-time random one-standard deviation shock on growth effectively dies out after 4 years. This suggests that public investment generates a weak investment response from the private sector, given the likely lags involved in private sector decisions. In contrast, the major effect of public investment on growth is direct (in the sense that it boosts domestic demand), with relatively weak multipliers.

To measure the impact on GDP, we adapt the rate of return metric suggested by Pereira (2000). The first element in this calculation is the accumulated percentage point impact on the level of GDP of a one-time random shock to real public investment. Abusing terminology (given the cointegration results), this is termed the long-run elasticity $(\sigma)$ as in Pereira (2000).

$$
\sigma=\frac{\partial Y / Y}{\partial I / I}
$$

To control for the size of public investment in the economy, this elasticity $\sigma$ is divided by the average public investment-to-GDP ratio since $1990(I / Y)_{\mathrm{A}}$. Since 1990, this ratio has exhibited stationarity, and the sample from which the average is chosen has little effect. This obtains the marginal product of investment $(M P)$ :

$$
M P=\sigma \cdot\left(\frac{Y}{I}\right)_{A}=\frac{d Y}{d I}
$$

To make the calculation simple, assume a one percent shock to public investment. The marginal output may then be assumed to flow over some realistic project horizon. In this case, a 20-year horizon with a constant output flow, that is ( $d Y$ / 20) per period. The rate of return on public investment $(r)$ is then the discount rate that solves the present value problem (5):

$1=\sum_{t=1}^{20} \frac{d Y}{(1+r)^{t}}$

The table below applies this method to the results from the estimate panel-VAR and the historical ECCU data. The baseline model is the two-lag model including OECD growth as an exogenous regressor. Two other specifications, including aid flows and a time trend, are shown. 
ECCU: Rate of Return on Public Investment

\begin{tabular}{|c|c|c|c|}
\hline & $\begin{array}{c}\text { Long-run } \\
\text { Elasticity } 1 /\end{array}$ & $\begin{array}{c}\text { Marginal } \\
\text { Productivity } 2 /\end{array}$ & $\begin{array}{c}\text { Annual Rate of } \\
\text { Return 3/ }\end{array}$ \\
\hline \multicolumn{4}{|l|}{ Baseline model } \\
\hline Upper bound 4/ & 0.08 & 0.76 & -2.4 \\
\hline Central tendency & 0.07 & 0.66 & -3.6 \\
\hline Lower bound 4/ & 0.06 & 0.54 & -5.3 \\
\hline \multicolumn{4}{|c|}{ Including aid flows as an exogneous regressor } \\
\hline Central tendency & 0.05 & 0.47 & -6.3 \\
\hline \multicolumn{4}{|c|}{ Including aid flows and a time trend } \\
\hline Central tendency & 0.07 & 0.61 & -4.3 \\
\hline
\end{tabular}

Source: Author's calculations.

1/ Accumulated log-change in the level of real GDP divided by the accumulated log-change in the level of real public investment due to a one-time one-percent shock in real public investment.

2/ Calculated as the long-run elasticity divided by the public investment - GDP ratio and interpreted as the long-run real EC dollar change in real GDP divided by the long-run change in real public investment.

$3 /$ This is the internal rate of average annual percentage rate of return implied by the marginal product of capital over a 20-year period.

4/ Bounds based on one-standard deviation confidence intervals on the change in growth and public investment.

These return estimates are compared in the table below to recent results from the literature; the rate of return estimated for the ECCU appears to be at the lower end of the range. Note that the return calculation is slightly different than in the table above. To ensure consistency with the literature, the return calculation below is based on the assumption that payoff to public investment arrives as a lump sum after 20 years. 
ECCU: Rate of Return Compared 1/

\begin{tabular}{llr}
\hline Countryl region & Study & Rate of Return \\
\hline ECCU & & $\mathbf{- 2 . 0}$ \\
& & \\
U.S. 2I & Pereira (2000) & 7.8 \\
Austria & Pereira and Fatima-Pinho (2006) & -6.2 \\
Belgium & $"$ & -7.9 \\
Finland & $"$ & 2.7 \\
France & $"$ & 6.7 \\
Germany & $"$ & 10.3 \\
Greece & $"$ & 7.6 \\
Ireland & $"$ & 6.8 \\
Italy & $"$ & 11.4 \\
Portugal & $"$ & 6.0 \\
Spain & & 3.8 \\
Average (excl. ECCU) & & 4.5 \\
Standard deviation (excl. ECCU) & & 6.2 \\
\hline
\end{tabular}

Source: Author's calculations; Pereira (2000); and Pereira and Fatima-Pinho (2006)

1/ Rate of return calculated as a "bullet" output flow after 20-years.

2/ Measured in terms of private output.

\section{Granger Causality Test—Public Investment on Output}

The conventional way to assess whether past changes in public investment affect the contemporaneous level of growth is a Granger causality test. For all three specifications, the hypothesis that public investment did not Granger cause output growth could be rejected at the 1 percent level of significance (using log likelihood tests, with and without small sample adjustments). These results should not be so surprising given that public investment, on average, accounts for over 9 percent of GDP, suggesting that demand effects alone could be significant.

\section{The Impact of Growth on Public Investment}

The effect of a growth shock on public investment is positive (see Figure 5). Higher growth may be supportive for tax and other revenues and allow the public sector to increase capital expenditure from its own resources. Standard errors are fairly wide, however. This is unsurprising. Ignoring the effect of natural disasters (which clearly play a role, even in the presence of some control variables), public investment in these economies may be influenced by factors outside of the model. The most obvious example is the availability of funds, whether from donors in the form of grants or concessionary loans, or from private sources. 


\section{E. The Impact of Public Investment and Growth on the Bilateral RER}

Impulse responses suggest that the bilateral RER appreciates in the first three years following positive public investment and growth shocks, but the standard errors are very wide (Figure 6). In the long-term, higher levels of public investment appear to have little effect in reversing this effect, suggesting the short-run demand impact on prices is much more important than the long-run supply effect.

\section{F. Effects of Natural Disaster and Elections}

The controls for natural disasters and elections worked as anticipated. The coefficients on both sets of dummies had the expected sign (see Table 3). The effects on growth were particularly pronounced, with growth falling sharply in the year of a disaster and then rising strongly the following year.

\section{CONCLUSIONS}

Public investment plays an important role in raising and sustaining economic growth in the region. However, public investment must be efficient if it is to have the desired growth effect and reduce the risks that it will add to public sector indebtedness. The evidence from the ECCU over the last 30 years suggests that public investment has had only a temporary and limited growth effect. To the extent that investment is financed by borrowing, this suggests that public investment has had a larger impact on the debt stock than on GDP.

This paper does not seek to explain why public investment is relatively inefficient. The methods used only help to make inferences regarding its impact on growth. It also does not address the differential effects of various types of public investment. Attempting to explain why the rate of return is low and what types of public investment are most productive in the eastern Caribbean remains a fertile area for future research. 


\section{APPENDIX}

Table 1. ECCU Public Investment Model: Summary Statistics

\begin{tabular}{lcccccc}
\hline & Observations & Mean & Max. & Min. & Std. dev. & Skew \\
\hline Public investment & 171 & 5.6 & 236.2 & -133.7 & 45.4 & 0.7 \\
Country GDP & 171 & 3.9 & 21.1 & -20.4 & 4.9 & -0.3 \\
Bilateral RER & 173 & 0.6 & 16.4 & -6.6 & 3.4 & 1.5 \\
OECD GDP & 29 & 2.8 & 4.5 & 0.2 & 1.1 & -0.4 \\
Aid flows & 174 & -11.4 & 160.0 & -1033.0 & 121.6 & -6.7 \\
\hline
\end{tabular}

Source: Author's calculations

1/ All statistics based on the first difference of the log of real variables multiplied by 100 .

Table 2. Correlation Matrix of Model Variables 1/

\begin{tabular}{|c|c|c|c|c|c|}
\hline & $\begin{array}{c}\text { Public } \\
\text { investment }\end{array}$ & $\begin{array}{c}\text { Country } \\
\text { GDP }\end{array}$ & $\begin{array}{c}\text { Bilateral } \\
\text { RER }\end{array}$ & $\begin{array}{c}\text { OECD } \\
\text { GDP }\end{array}$ & $\begin{array}{c}\text { Aid } \\
\text { flows }\end{array}$ \\
\hline Public investment & - & & & & \\
\hline Country GDP & $0.208^{\star \star \star}$ & - & & & \\
\hline Bilateral RER & 0.049 & -0.129 & - & & \\
\hline OECD GDP & 0.101 & $0.352^{\star \star \star}$ & -0.244 & - & \\
\hline Aid flows & 0.108 & 0.045 & 0.044 & 0.002 & - \\
\hline
\end{tabular}

Source: Author's calculations

1 / Correlations use first difference of the log of real variables. ${ }^{* *}$ indicates that the correlation coefficient is significant at the 1 percent level.

Table 3. VAR Coefficients on Natural Disaster and Election Dummy Variables

\begin{tabular}{|c|c|c|c|}
\hline & $\begin{array}{c}\text { Public } \\
\text { Investment }\end{array}$ & $\begin{array}{l}\text { Real } \\
\text { GDP } \\
\end{array}$ & $\begin{array}{c}\text { Bilateral } \\
\text { RER }\end{array}$ \\
\hline \multicolumn{4}{|c|}{ Natural disaster (same year) } \\
\hline coefficient & -36.4 & -6.2 & 2.9 \\
\hline standard error & 32.5 & 2.5 & 1.9 \\
\hline \multicolumn{4}{|c|}{ Natural disaster (following year) } \\
\hline coefficient & 24.6 & 16.5 & -1.7 \\
\hline standard error & 36.8 & 6.8 & 2.4 \\
\hline \multicolumn{4}{|c|}{ Election (preceding year) } \\
\hline coefficient & 12.1 & 1.2 & 0.3 \\
\hline standard error & 15.0 & 1.2 & 0.8 \\
\hline \multicolumn{4}{|c|}{ Election (same year) } \\
\hline coefficient & 20.0 & 0.6 & -0.8 \\
\hline standard error & 19.4 & 1.4 & 0.8 \\
\hline
\end{tabular}

Source: Author's calculations. 
Figure 1. ECCU: Public Investment, Growth and Aid Inflows, 1975-2004

Public Investment (percent of GDP)

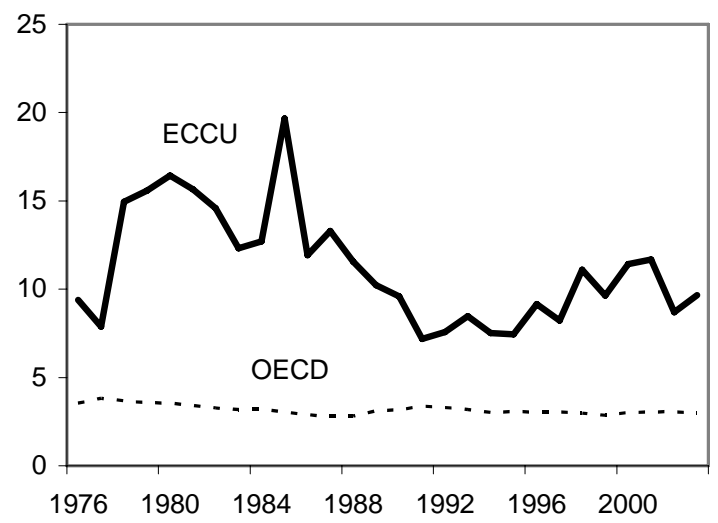

Public Investment and Aid Inflows (percent of GDP)

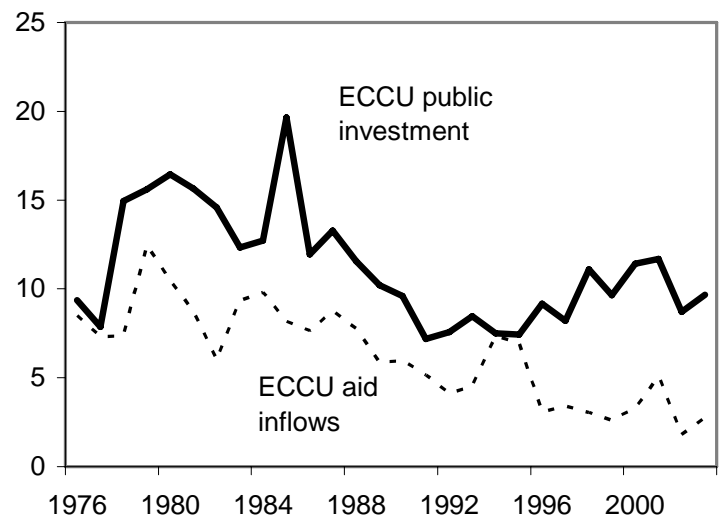

Public Investment and GDP growth

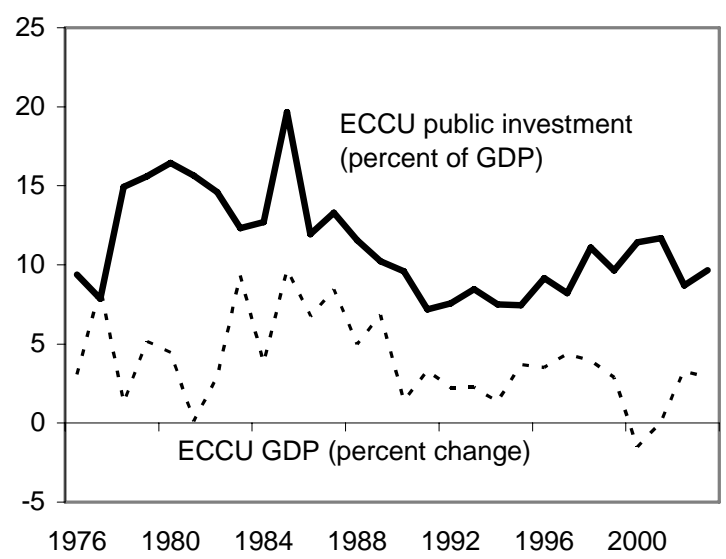

Public Investment, GDP, and the RER (constant prices, 1980 $=100$ ))

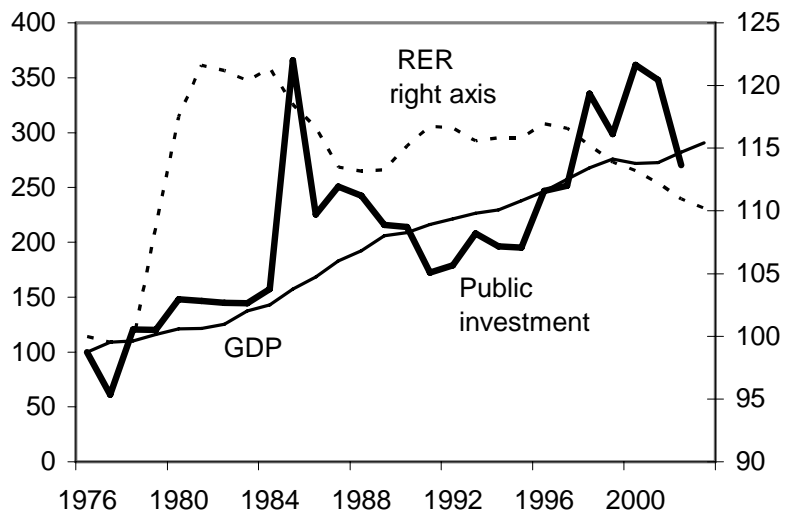

Public Investment and Aid Inflows (percent of GDP)

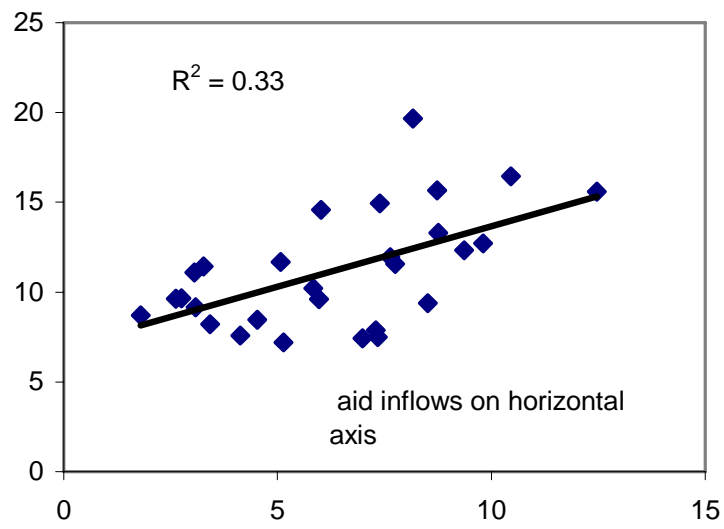

GDP growth and Aid Inflows

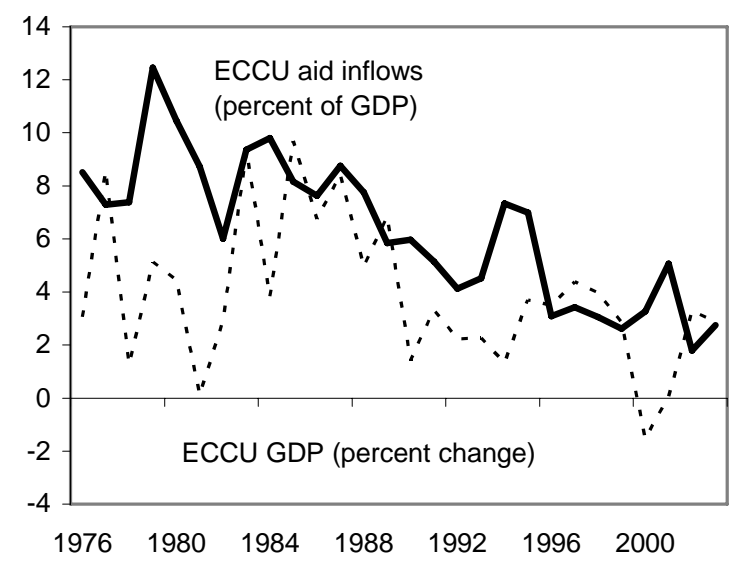

Source: National authorities; Organization for Economic Co-operation and Development; and author's calculations. 
Figure 2. ECCU: Public Sector Investment, 1975-2004

(Percent of GDP)

Antigua and Barbuda

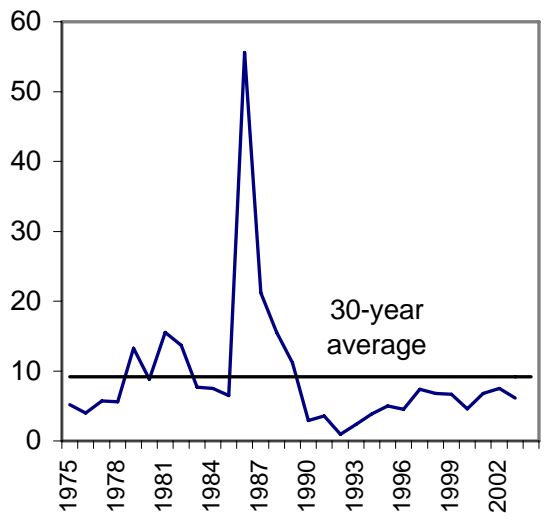

Grenada

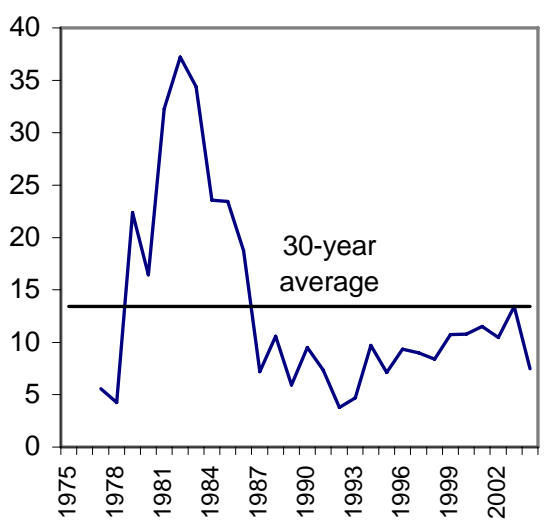

St. Lucia

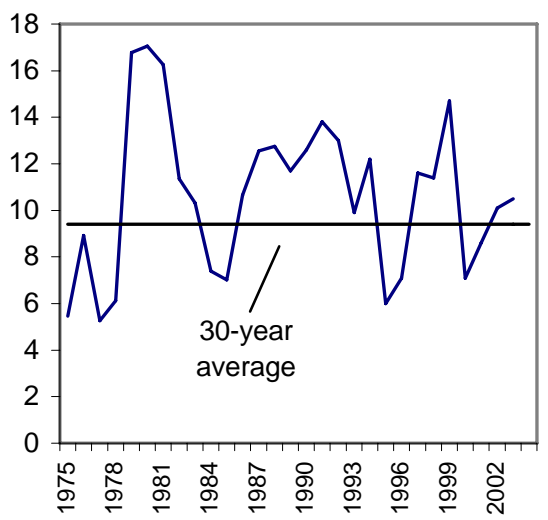

Dominica

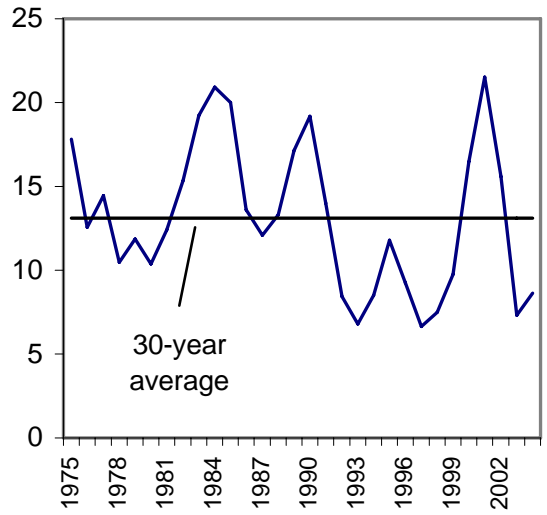

St. Kitts and Nevis

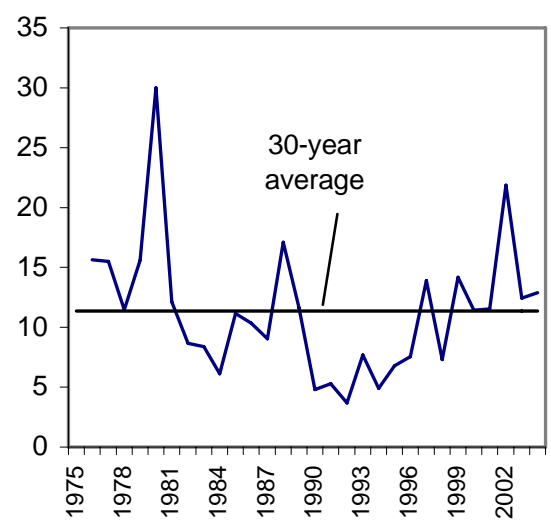

St. Vincent and the Grenadines

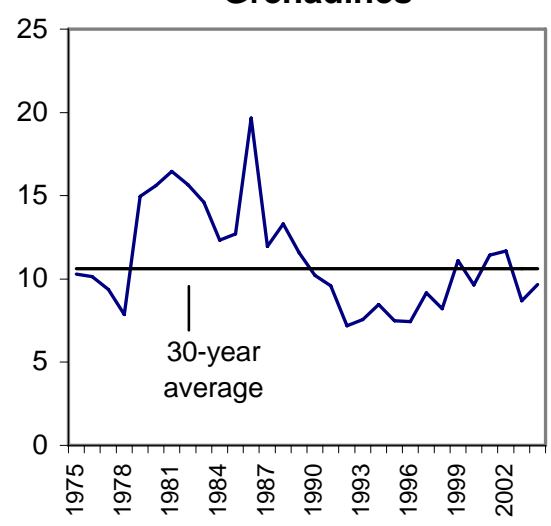

Source: Country authorities; ECCB; World Bank; IMF; and author's calculations. 
Figure 3. ECCU: Impulse Response for GDP and the Bilateral Real Exchange Rate to One Standard-Deviation Public Investment and GDP Shocks

\section{Response of GDP to}

Public Investment and GDP shocks

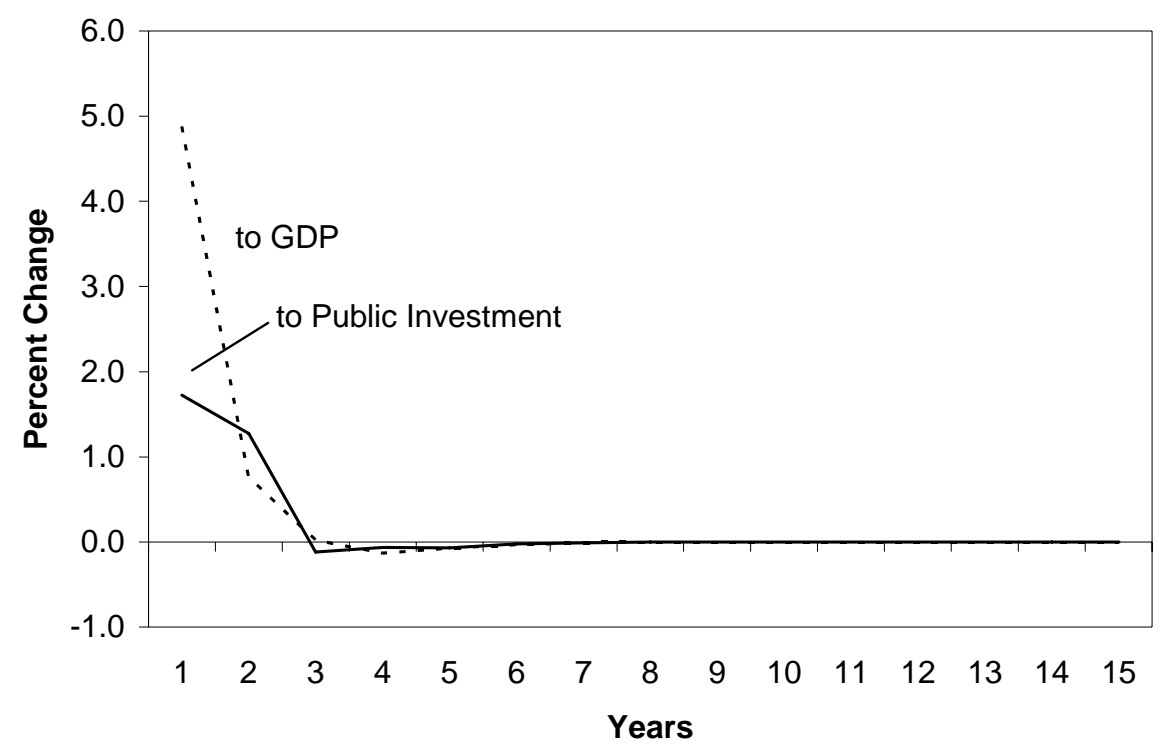

Response of the RER to

Public Investment and GDP shocks

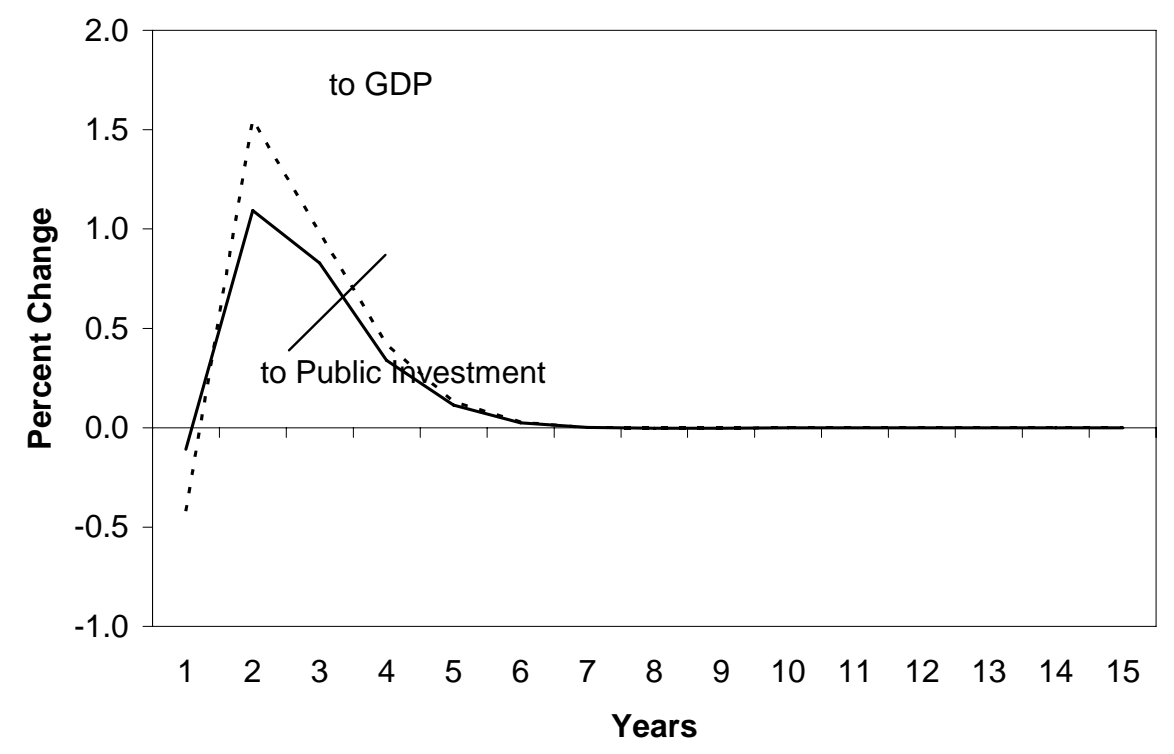

Source: Author's calculations. 
Figure 4. ECCU: Accumulated Impulse Responses to a One Standard Deviation Shock to Public Investment

\section{Response of Public Investment 1/}

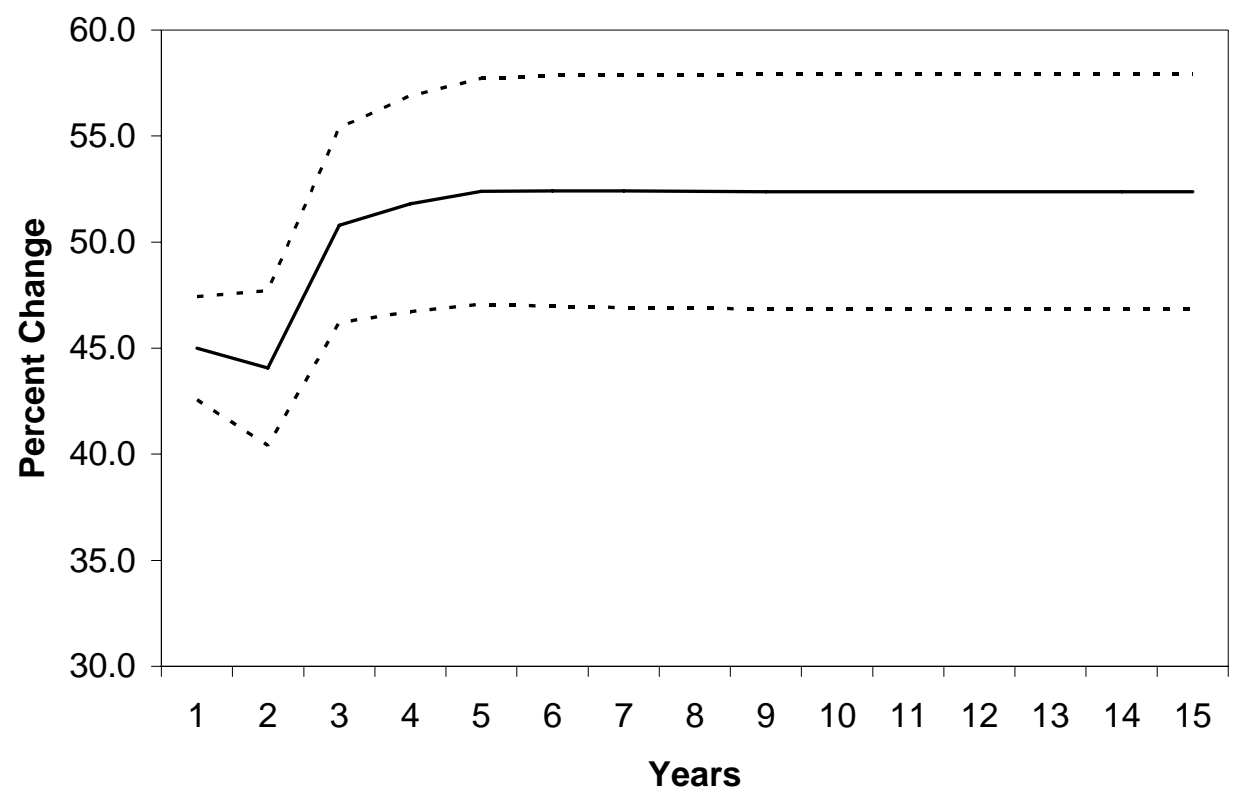

Response of GDP 1/

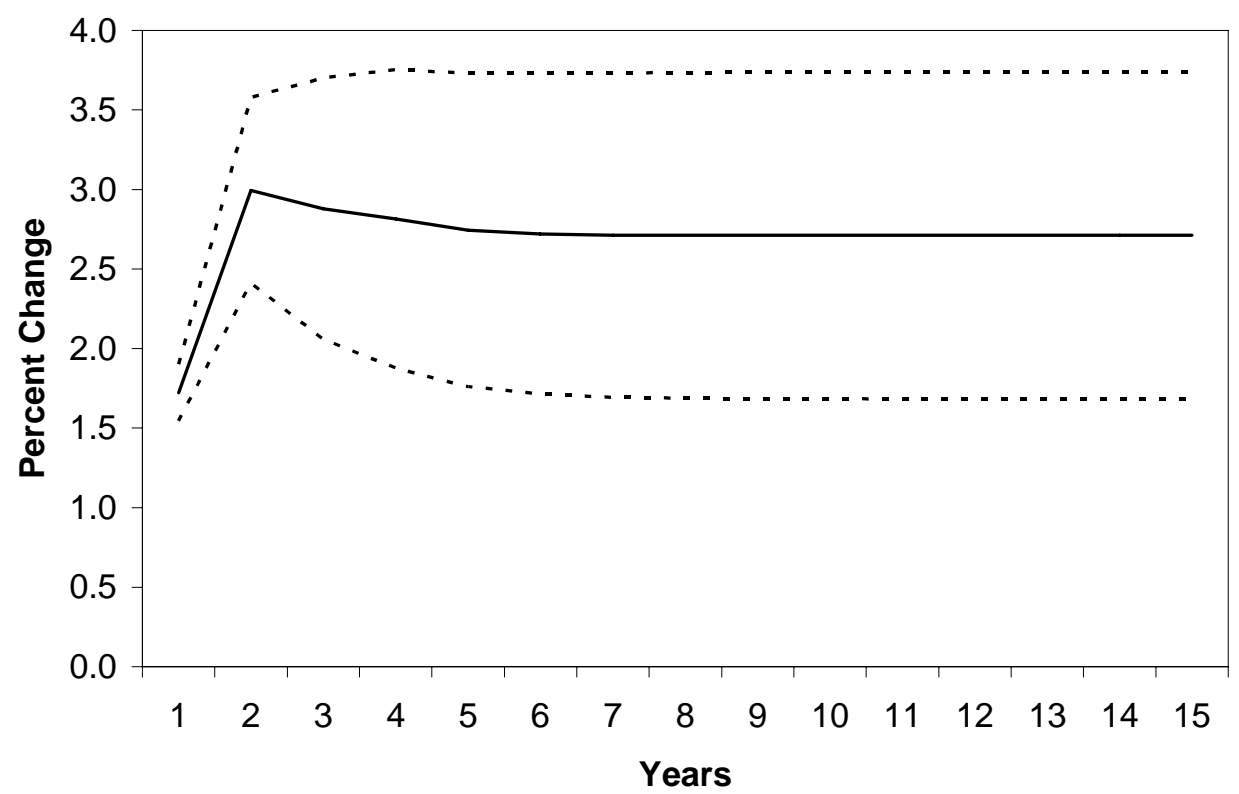

Source: Author's calculations.

1/ Standard error bounds calculated using Monte Carlo simulations. 
Figure 5. ECCU: Accumulated Impulse Responses

to a One Standard Deviation Shock to GDP

Response of Public Investment $\mathbf{1 /}$

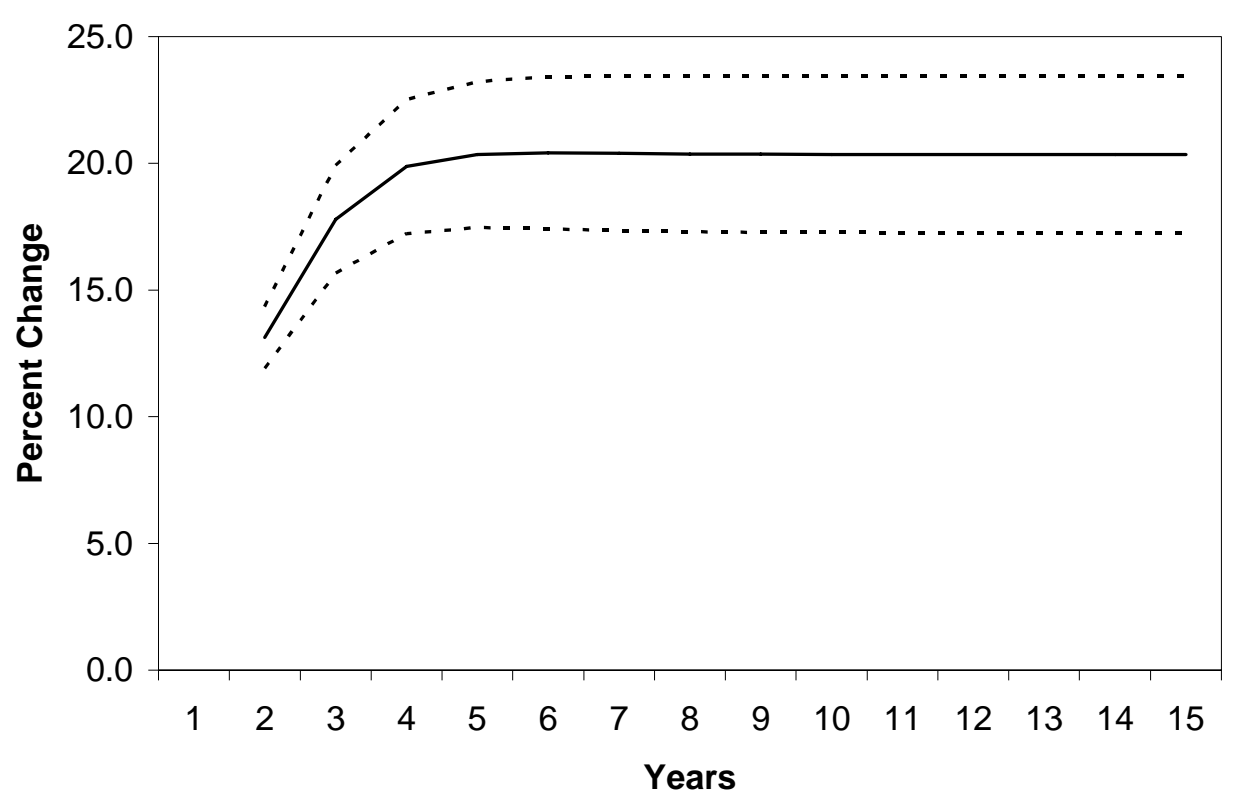

Response of GDP 1/

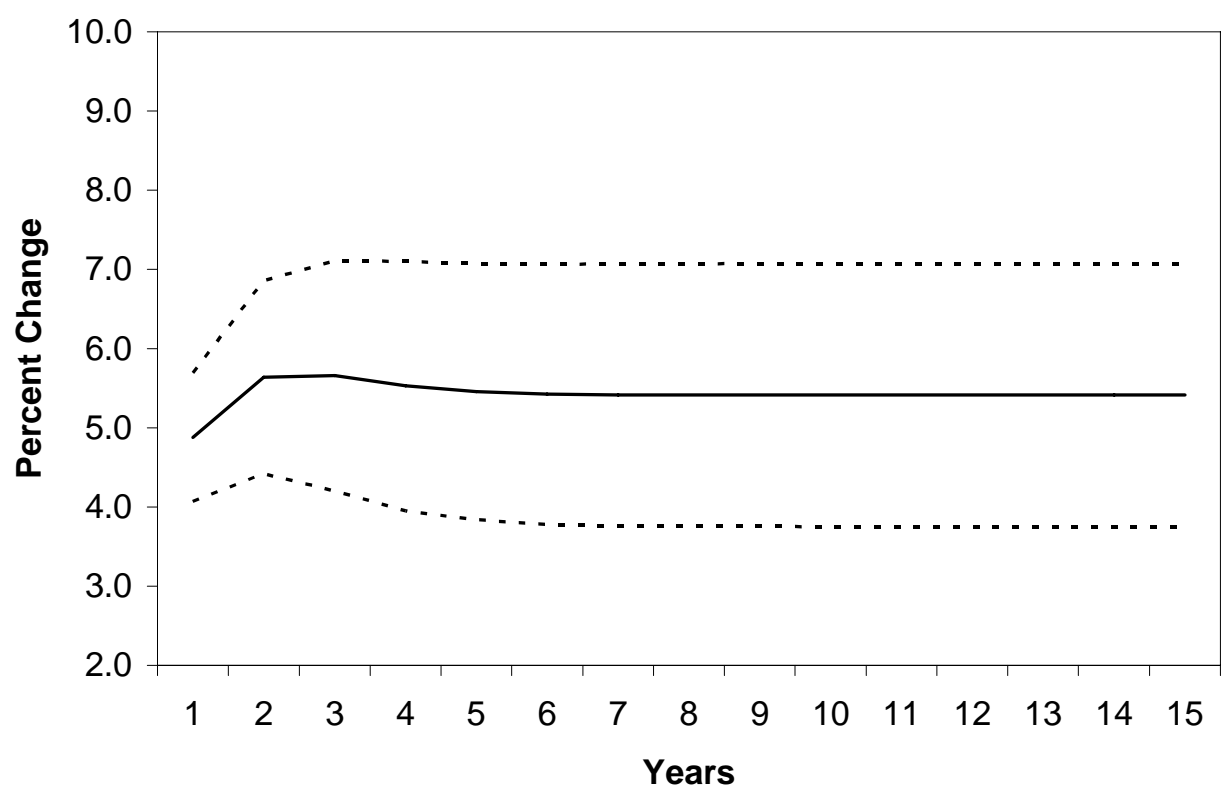

Source: Author's calculations.

1/ Standard error bounds calculated using Monte Carlo simulations. 
Figure 6. ECCU: Accumulated Impulse Responses of the Bilateral RER to a One Standard Deviation Shock to GDP and Public Investment

\section{Response to Public Investment 1/}

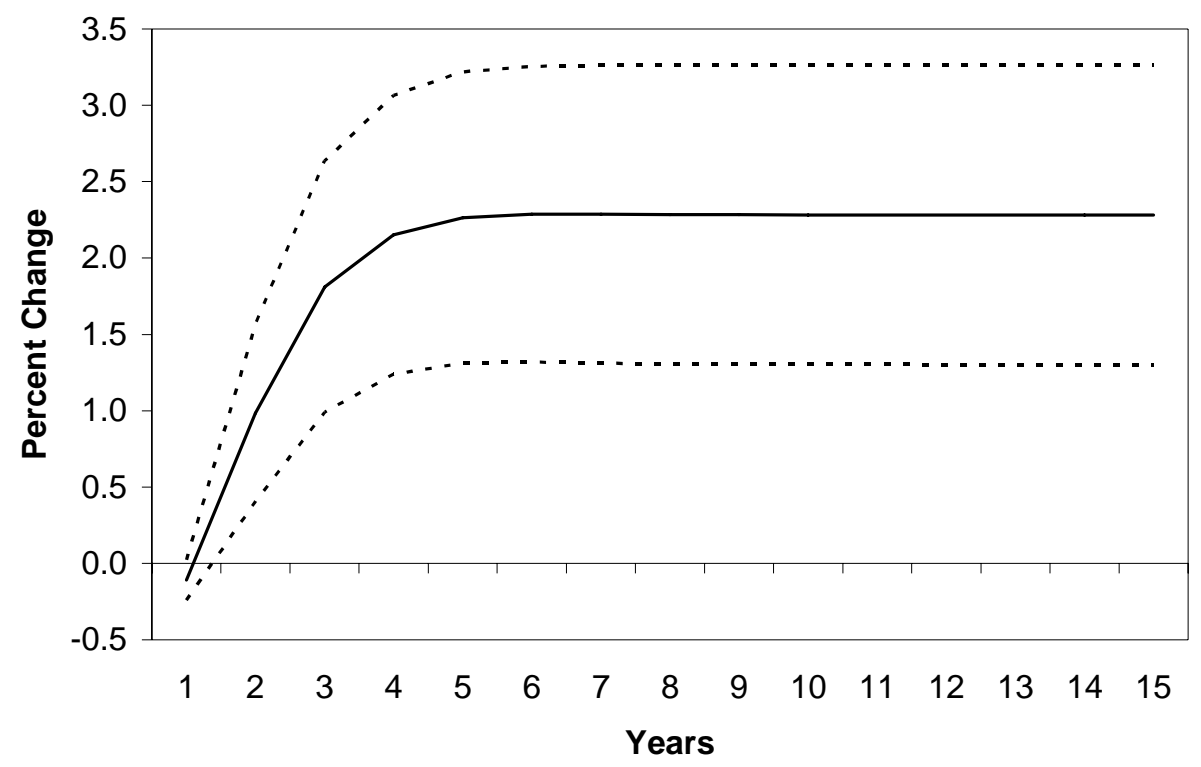

\section{Response to GDP 1/}

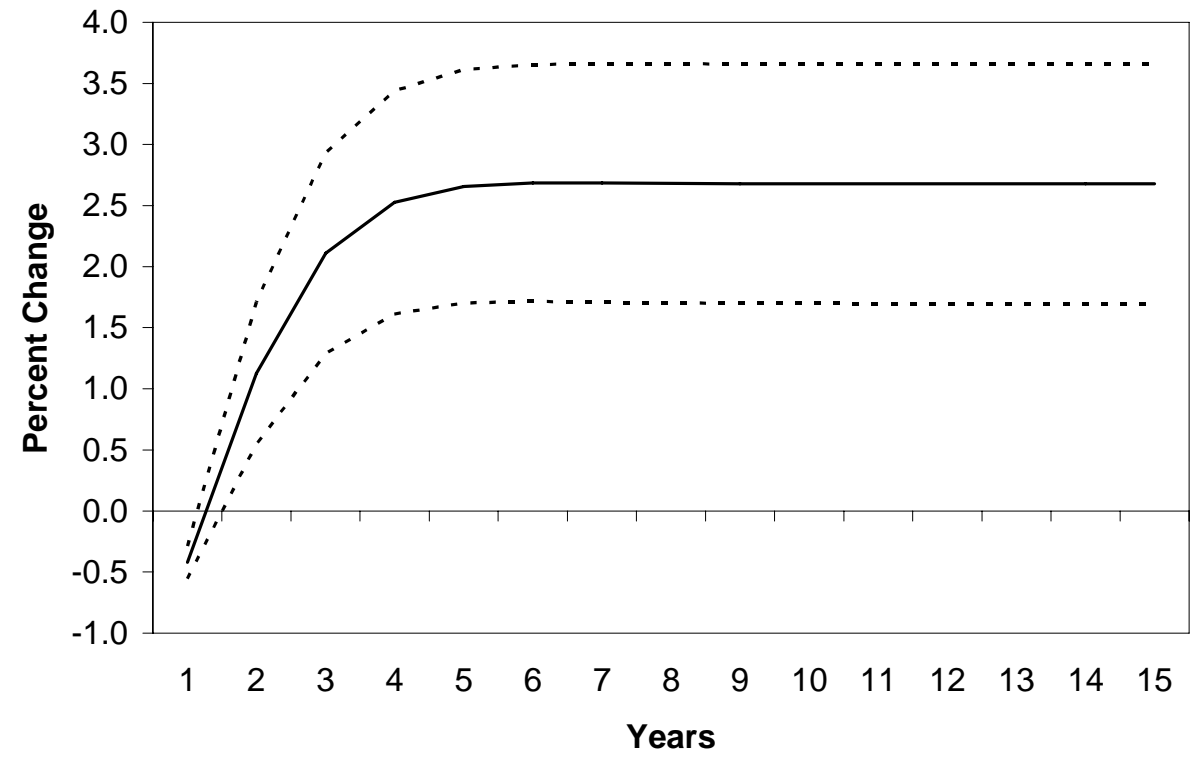

Source: Author's calculations.

1/ Standard error bounds calculated using Monte Carlo simulations. 


\section{REFERENCES}

Aschauer, D.,1989a, “Is Public Expenditure Productive,?” Journal of Monetary Economics, 23, pp. 177-200.

Aschauer, D., 1989b, “Does Public Capital Crowd Out Private Capital,” Journal of Monetary Economics, 24, pp. 171-88.

Duttagupta, Rupa, and Guillermo Tolosa, 2006, “Fiscal Discipline and Exchange Rate Regimes: Evidence from the Caribbean,” IMF Working Paper, 06/119, (Washington D.C.: International Monetary Fund).

Hamilton, James, D., 1994, “Time Series Analysis,” Princeton University Press, Princeton, New Jersey.

Holtz-Eakin, D., Newey, W., and H. S. Rosen, 1988, "Estimating Vector Autoregressions with Panel Data,” Econometrica, 56, pp. 1371-95.

Jorgenson, D., 1990, “Fragile Statistical Foundations,” The Public’s Capital, pp. 6-7.

Judson, R., and A. L. Owen, 1996, “Estimating Dynamic Panel Data Models:

A Practical Guide for Macroeconomists,” Federal Reserve Board of Governors, Washington D.C.

Kamps, Christophe, 2004, The Dynamic Macroeconomic Effects of Public Capital-Theory and Evidence for OECD Countries, Springer-Verlag, Berlin.

Kavanagh, Catherine, 1997, "Public Capital and Private Sector Productivity in Ireland, 1958-90,” Journal of Economic Studies, Vol. 24, No. 1/2, pp. 72-94.

Khan, Mohsin S., and Manmohan S. Kumar, 1997, "Public and Private Investment and the Growth Process in Developing Countries," Oxford Bulletin of Economics and Statistics, Vol. 59, No. 1, pp. 69-88.

Mlachila, Montfort, and Paul Cashin, 2007, “The Macroeconomic Impact of Trade Preference Erosion on the Windward Islands,” Eastern Caribbean Currency Union: Selected Issues, IMF Country Report No. 07/97, pp. 18-43 (Washington D.C.: International Monetary Fund).

Munnell, A., 1992, “Infrastructure Investment and Economic Growth,” Journal of Economic Perspectives, 6, pp. 189-98.

Nickell, Stephen, 1981, “Biases in Dynamic Models with Fixed Effects,” Econometrica, 49, pp. 1417-26. 
Pereira, Alfredo M., 2000, “Is All Public Capital Created Equal?,” Review of Economics and Statistics, Vol. 82, No. 3, pp. 513-18.

Pereira, Alfredo M., and Maria de Fatima-Pinho, 2006, "Public Investment, Economic Performance, and Budgetary Consolidation: VAR Evidence for the 12 Euro Countries," College of William \& Mary, Working Paper No. 40.

Roache, Shaun K., 2006, "Domestic Investment and the Cost of Capital in the Caribbean,” IMF Working Paper 06/152 (Washington D.C.: International Monetary Fund). 